Rev. Bras. Saúde Prod. Anim., Salvador, v.17, n.2, p.162-173 abr./jun., 2016 http://www.rbspa.ufba.br

\title{
Relações metionina + cistina: lisina digestíveis para codornas de corte machos em fase de terminação
}

\author{
Relations of methionine plus cystine to lysine digestible of males meat quails in \\ termination phase
}

\author{
CASTRO, Mariana Resende de ${ }^{*}$; PINHEIRO, Sandra Regina Freitas ${ }^{1}$; LIMA, Heder \\ José D’Ávila²; PIRES, Aldrin Vieira ${ }^{1}$; VIEIRA, Dayane Josiane ${ }^{1}$; ABREU, Luíza \\ Rodrigues Alves ${ }^{1}$; MOTA, Lúcio Flávio Macedo ${ }^{1}$; OLIVEIRA, Renata Gomes ${ }^{1}$
}

\begin{abstract}
${ }^{1}$ Universidade Federal dos Vales do Jequitinhonha e Mucuri, Programa de Pós-Graduação em Zootecnia, Diamantina, Minas Gerais, Brasil.

${ }^{2}$ Universidade Federal de Mato Grosso, Faculdade de Agronomia, Medicina Veterinária e Zootecnia, Cuiabá, Mato Grosso, Brasil.

*Email para correspondência: marianaresendec@gmail.com
\end{abstract}

\section{RESUMO}

Com o objetivo de estimar as melhores relações metionina + cistina: lisina digestíveis para codornas de corte machos durante os períodos de 22 a 28 e 29 a 35 dias de idade foram desenvolvidos dois experimentos. As aves foram submetidas a uma ração basal deficiente em metionina + cistina digestível, sendo esta suplementada com cinco níveis de DL-Metionina, em substituição ao ácido glutâmico e amido, resultando nas seguintes relações metionina + cistina: lisina digestíveis: 0,$68 ; 0,73 ; 0,78 ; 0,83$ e 0,88 . Foram utilizadas 280 codornas distribuídas em delineamento inteiramente casualizado, com cinco tratamentos, oito repetições de sete aves por parcela. Avaliou-se o consumo de ração, ganho de peso, conversão alimentar, rendimento de carcaça, empenamento das aves, composição química da carcaça e balanço de nitrogênio. Durante o período de 22 a 28 dias de idade não houve efeito para as variáveis estudadas frente às relações + cistina: lisina digestíveis. Para o período de 29 a 35 dias de idade observou-se efeito para o consumo de ração, consumo de metionina + cistina e o ganho de peso. Aos 35 dias de idade observou-se efeito para o rendimento de coxa e sobrecoxa, extrato etéreo e proteína bruta da carcaça e para a retenção de nitrogênio. Recomendam-se as relações + metionina + cistina : lisina digestíveis de 0,68 e 0,88 durante os períodos de 22 a 28 e 29 a 35 dias de idade, respectivamente.

Palavras-chave: aminoácidos, balanço de nitrogênio, composição da carcaça, proteína ideal

\section{SUMMARY}

In order of estimating the best relations methionine plus cystine: digestible lysine for quails males during the periods 22 to 28 and 29 to 35 days of age were developed two experiments. The quails received a basal diet deficient in methionine plus cystine, which were supplemented with five levels of DLMethionine, replacing glutamic acid and starch, resulting in the following relations: $0.68,0.73$, $0.78,0.83$ and 0.88 . A total of 280 quails distributed in a completely randomized design, with five treatments and eight replicates of seven quails per experimental unit. Feed intake, body weight gain, feed conversion, carcass yield and feathering of quails, composition of the carcass and nitrogen balance were evaluate. During the period from 22 to 28 days of age there was no effect for the variables studied front to relations methionine plus cystine : digestible lysine. During the period 29 to 35 days of age was observed effect on feed intake, methionine + cystine intake and weight gain. At 35 days old was observed effect on the yield of thigh and drumstick, ether extract and crude protein carcass and nitrogen retention. Are recommended that the relations methionine plus cystine : digestible lysine 0.68 and 0.88 over the period 22 to 28 and 29 to 35 days of age, respectively.

Keywords: amino acids, body composition, ideal protein, nitrogen balance 
Rev. Bras. Saúde Prod. Anim., Salvador, v.17, n.2, p.162-173 abr./jun., 2016 http://www.rbspa.ufba.br

\section{INTRODUÇÃO}

Com o intuito de maximizar a produtividade e minimizar os custos de produção e a poluição ambiental, algumas estratégias devem ser adotadas pelas cadeias de produção animal. Entre estas estratégias, o uso do conceito da proteína ideal nas formulações de rações tem motivado as pesquisas, uma vez que, possibilita a redução da poluição pela menor excreção de nitrogênio (SARAIVA et al., 2006; TON et al., 2013), melhora o desempenho animal por utilizar ingredientes mais digestíveis, e possibilita a redução da proteína bruta das rações.

De acordo com o conceito de proteína ideal, todos os aminoácidos devem estar na quantidade exata para atender as exigências para manutenção, crescimento e produção. No entanto, vários fatores intrínsecos e extrínsecos podem alterar as exigências dos animais (ROSTAGNO et al., 2011). Embora as exigências quantitativas dos aminoácidos possam ser influenciadas por estes fatores, as proporções entre eles permanecem constantes (EMMERT \& BAKER, 1997).

Para as codornas a metionina é o primeiro aminoácido limitante em rações formuladas principalmente por milho e farelo de soja (SILVA et al., 2012), pois exigem grandes quantidades deste aminoácido para o crescimento, manutenção e formação de penas. Costa et al. (2008) relataram que a lisina é o segundo aminoácido limitante nas rações para aves e ela pode afetar o desempenho das codornas, tanto pela deficiência quanto pelo excesso. A lisina é utilizada como aminoácido referência para calcular rações com base no conceito de proteína ideal.

Com base nestes relatos, objetivou-se com este trabalho estimar as melhores relações metionina + cistina: lisina digestíveis em rações para codornas de corte machos durante os períodos de 22 a 28 e 29 a 35 dias de idade, e seus efeitos sobre os parâmetros de desempenho, empenamento, composição química da carcaça e balanço de nitrogênio.

\section{MATERIAL E MÉTODOS}

Foram conduzidos dois experimentos no Laboratório de Pesquisas com Animais Monogástricos, do Departamento de Zootecnia, Campus JK, da Universidade Federal dos Vales do Jequitinhonha e Mucuri, durante o período de julho a dezembro de 2013. O protocolo experimental foi aprovado pelo Comitê de Ética no Uso de Animais (CEUA) com o número: 032/2012.

Foram utilizadas 280 codornas de corte macho durante os períodos de 22 a 28 e 29 a 35 dias de idade, com peso médio inicial de $153,91 \pm 1,21 \mathrm{~g}$ e $201,89 \pm$ $2,26 \mathrm{~g}$, respectivamente, e distribuídas em delineamento inteiramente casualizado com cinco tratamentos, oito repetições e sete aves por parcela.

As codornas foram alojadas em gaiolas confeccionadas em arame galvanizado (60 largura x 60 comprimento x 35 altura, $\mathrm{cm}$ ), dispostas em três baterias de quatro andares. Cada gaiola equipada com um bebedouro tipo copo de pressão e um comedouro tipo calha, posicionado na parte frontal da gaiola. A temperatura ambiente foi monitorada duas vezes ao dia (8:00h e 15:00h) com o auxilio de termômetros digitais instalados em cada bateria.

As aves foram alimentadas com uma ração formulada principalmente com milho e farelo de soja, contendo $0,63 \%$ de metionina + cistina digestível, correspondendo à relação de metionina + cistina: lisina digestível de 0,68. Esta ração foi suplementada com 5 níveis de 
Rev. Bras. Saúde Prod. Anim., Salvador, v.17, n.2, p.162-173 abr./jun., 2016 http://www.rbspa.ufba.br ISSN 15199940

DL-metionina (99\%), em substituição ao ácido glutâmico em equivalente proteico e ao amido em equivalente energético, correspondendo às relações metionina + cistina : lisina digestíveis de 0,$68 ; 0,73$; 0,$78 ; 0,83$ e 0,88 , de modo que todas as rações permaneceram isoproteicas $\mathrm{e}$ isoenergéticas.

As rações experimentais (Tabela 1) foram balanceadas com base no conteúdo aminoacídico digestível dos alimentos, apresentado por Rostagno et al. (2011), e segundo as exigências nutricionais recomendadas por Silva \& Costa (2009), exceto para lisina digestível que adotouse o nível sub-ótimo, correspondente à subtração de $10 \%$ do nível recomendado. Foram mantidas as relações aminoacídicas com a lisina propostas por Silva \& Costa (2009), exceto para metionina + cistina digestível. Para assegurar ausência de deficiências, foram acrescentados 3\% nas exigências de cada aminoácido, exceto para lisina $\mathrm{e}$ metionina + cistina digestível.

Tabela 1. Composição e valor nutricional das rações experimentais, na matéria natural, para codornas de corte de 22 a 28 e 29 a 35 dias de idade

\begin{tabular}{|c|c|c|c|c|c|}
\hline \multirow{2}{*}{ Ingredientes } & \multicolumn{5}{|c|}{ Relações metionina + cistina: lisina } \\
\hline & 0,68 & 0,73 & 0,78 & 0,83 & 0,88 \\
\hline Milho Moído & 61,09 & 61,09 & 61,09 & 61,09 & 61,09 \\
\hline Farelo de Soja (45\%) & 30,45 & 30,45 & 30,45 & 30,45 & 30,45 \\
\hline Glúten de Milho (60\%) & 4,70 & 4,70 & 4,70 & 4,70 & 4,70 \\
\hline Calcário Calcítico & 1,02 & 1,02 & 1,02 & 1,02 & 1,02 \\
\hline Fosfato Bicálcico & 0,87 & 0,87 & 0,87 & 0,87 & 0,87 \\
\hline Sal Comum & 0,35 & 0,35 & 0,35 & 0,35 & 0,35 \\
\hline Mistura Mineral $^{(1)}$ & 0,20 & 0,20 & 0,20 & 0,20 & 0,20 \\
\hline Mistura Vitamínica $^{(2)}$ & 0,20 & 0,20 & 0,20 & 0,20 & 0,20 \\
\hline Cloreto de Colina (60\%) & 0,01 & 0,01 & 0,01 & 0,01 & 0,01 \\
\hline DL- Metionina (99\%) & 0,00 & 0,04 & 0,09 & 0,13 & 0,19 \\
\hline L- Arginina (99\%) & 0,11 & 0,11 & 0,11 & 0,11 & 0,11 \\
\hline L-Glutâmico (99,4\%) & 0,50 & 0,45 & 0,40 & 0,36 & 0,30 \\
\hline Amido & 0,50 & 0,51 & 0,51 & 0,51 & 0,51 \\
\hline Total & 100,00 & 100,00 & 100,00 & 100,00 & 100,00 \\
\hline \multicolumn{6}{|l|}{ Composição calculada } \\
\hline Energia Metabolizável (kcal/kg) & 2.900 & 2.900 & 2.900 & 2.900 & 2.900 \\
\hline Proteína Bruta $(\%)$ & 21,73 & 21,73 & 21,73 & 21,73 & 21,73 \\
\hline Cálcio (\%) & 0,70 & 0,70 & 0,70 & 0,70 & 0,70 \\
\hline Fósforo Disponível (\%) & 0,27 & 0,27 & 0,27 & 0,27 & 0,27 \\
\hline Sódio $(\%)$ & 0,15 & 0,15 & 0,15 & 0,15 & 0,15 \\
\hline Fibra Bruta (\%) & 2,70 & 2,70 & 2,70 & 2,70 & 2,70 \\
\hline \multicolumn{6}{|l|}{ Aminoácidos digestíveis (\%) } \\
\hline Lisina & 0,920 & 0,920 & 0,920 & 0,920 & 0,920 \\
\hline Metionina + Cistina & 0,630 & 0,670 & 0,720 & 0,760 & 0,810 \\
\hline Triptofano & 0,220 & 0,220 & 0,220 & 0,220 & 0,220 \\
\hline Treonina & 0,733 & 0,733 & 0,733 & 0,733 & 0,733 \\
\hline Arginina & 1,370 & 1,370 & 1,370 & 1,370 & 1,370 \\
\hline Isoleucina & 0,843 & 0,843 & 0,843 & 0,843 & 0,843 \\
\hline Valina & 0,927 & 0,927 & 0,927 & 0,927 & 0,927 \\
\hline
\end{tabular}


As características avaliadas foram $\mathrm{o}$ consumo de ração (g/ave), consumo de metionina + cistina (mg/ave), ganho de peso (g/ave), conversão alimentar $(\mathrm{g} / \mathrm{g})$, uniformidade (\%) e viabilidade (\%) foram avaliadas em todos os períodos experimentais. $\mathrm{O}$ consumo de ração por ave foi corrigido pela data da mortalidade, quando houve. Para a uniformidade considerou-se uma variação de $\pm 10 \%$ da média de peso do lote.

Aos 35 dias de idade, foram avaliadas as características de rendimento de carcaça, peso de penas e composição química da carcaça em gordura, proteína e matéria seca. Para isso, quatro codornas de cada unidade experimental foram amostradas aleatoriamente e abatidas. Após jejum alimentar de 6 horas, duas aves amostradas de cada parcela foram pesadas individualmente e identificadas com etiqueta na pata. Foi procedida a insensibilização pela secção da medula espinhal, seguida por sangria com espera por dois minutos, realizada a escaldagem com a temperatura controlada de 53 a $55^{\circ} \mathrm{C}$, por 20 a 40 segundos e retiradas as penas em depenadeira elétrica. Em seguida foi realizada a evisceração. As carcaças evisceradas foram colocadas em banho pré-chiller em temperatura de $4^{\circ} \mathrm{C}$, por aproximadamente 30 minutos.

Em seguida foram realizados os cortes para obtenção do peso da carcaça (sem pés e cabeça) e peso de cortes nobres (peito e coxa+sobrecoxa). Foram avaliadas as seguintes características: peso corporal (g/ave), peso carcaça (g/ave), rendimento de carcaça (\%), rendimento de peito $(\%)$ e rendimento de coxa+sobrecoxa (\%). O rendimento de carcaça foi obtido em relação ao peso corporal e os rendimentos de peito e de coxa+sobrecoxa foram obtidos em relação ao peso da carcaça, ambos multiplicados por 100 .
Para determinar o peso de penas, utilizouse duas aves amostradas por unidade experimental, totalizando 16 codornas por tratamento, que foram pesadas imediatamente após a etapa de insensibilização. Depois de sacrificadas, foi procedida realização da escaldagem e a retirada das penas manualmente, posteriormente as aves foram secas com papéis toalha e pesadas novamente. $\mathrm{O}$ peso das penas foi obtido pela diferença do peso das codornas com penas menos o peso sem penas.

Essas mesmas aves foram usadas para determinar a composição química da carcaça em proteína, gordura e matéria seca. Para isso, as carcaças foram evisceradas manualmente, lavadas e congeladas $\quad\left(-18^{\circ} \mathrm{C}\right)$ em sacos plásticos devidamente identificados. Posteriormente as carcaças (com pés e cabeça) foram moídas em moinho de carne industrial, homogeneizadas, pesadas e levadas à estufa de ventilação forçada a $55^{\circ} \mathrm{C}$ por 96 horas para a realização da pré-secagem. As carcaças pré-secas foram moídas em moinho tipo bola, e seguiram para análises da composição química da carcaça, conforme metodologia descrita por Silva \& Queiróz (2004).

O balanço de nitrogênio foi determinado no período de 29 a 35 dias de idade, assim, durante o $30^{\circ}$ ao $34^{\circ}$ dias de idade das codornas, foi realizada a técnica de coleta total de excretas. As excretas foram coletadas, desprovidas de penas e ração, duas vezes ao dia, acondicionadas em sacos plásticos identificados e congelados $\left(-18^{\circ} \mathrm{C}\right)$ para posteriores análises. As excretas foram homogeneizadas e pesadas de acordo com as respectivas parcelas e após estes procedimentos uma amostra representativa de $100 \mathrm{~g}$ foi pré-seca em estufa de ventilação forçada a $55^{\circ} \mathrm{C}$ por 36 horas. As amostras foram moídas em moinho de facas com peneira de $0,01 \mathrm{~cm}$. $\mathrm{O}$ cálculo foi determinado pela diferença 
Rev. Bras. Saúde Prod. Anim., Salvador, v.17, n.2, p.162-173 abr./jun., 2016 http://www.rbspa.ufba.br ISSN 15199940

entre o consumo de nitrogênio e a excreção de nitrogênio, ou seja, retenção de nitrogênio.

As análises da ração e excretas foram realizadas de acordo com a metodologia proposta por Silva \& Queiróz (2004), para matéria seca e nitrogênio total.

Os resultados das variáveis avaliadas foram submetidos às análises de variância, e análises de regressão, considerando as relações metionina + cistina: lisina digestível como variável independente, conforme os modelos de regressão polinomial simples ou quadrática e Linear Response Platô (LRP), a 5\% de probabilidade. Para verificar $o$ ajuste dos modelos foi considerado a soma dos quadrados dos desvios e os coeficientes de determinação $\left(\mathrm{R}^{2}=\mathrm{SQ}\right.$ Regressão / SQ tratamentos).

\section{RESULTADOS E DISCUSSÃO}

As temperaturas médias obtidas durante $\mathrm{o}$ período experimental foram de $28,67^{\circ} \mathrm{C} \pm$ 1,57 (máxima) e $23,03^{\circ} \mathrm{C} \pm 1,04$ (mínima) durante o período de 22 a 28 dias e $28,26^{\circ} \mathrm{C} \pm 1,89$ (máxima) e $22,59^{\circ} \mathrm{C} \pm 2,09$ (mínima) durante $\mathrm{o}$ período de 29 a 35 dias de idade. Com base nesses valores, pode-se inferir que as temperaturas médias (máxima e mínima) ficaram fora da zona de conforto térmico, apresentando-se em moderado estresse por calor, de acordo com Souza (2013), que considerou as temperaturas de $26^{\circ} \mathrm{C} \mathrm{e}$ $25^{\circ} \mathrm{C}$, as temperaturas de conforto térmico para codornas de corte criadas durante a terceira e quarta semana de vida, respectivamente.

As crescentes relações metionina + cistina : lisina digestíveis na ração das codornas não influenciaram $(\mathrm{P}>0,05)$ as variáveis de desempenho durante o período 22 a 28 dias de idade codornas de corte (Tabela 2). Portanto, a menor relação $(0,68)$ foi suficiente para atender as exigências de crescimento das codornas de corte machos durante este período.

Durante o período de 28 a 35 dias de idade observou-se efeito linear $(\mathrm{P}<0,01)$ crescente para o consumo de ração (CR $\left.=153,276+75,103 \mathrm{X} ; \mathrm{R}^{2}=0,59\right) \mathrm{de}$ acordo com o aumento das relações metionina + cistina : lisina digestíveis na ração (Tabela 3, Figura 1).

Tabela 2. Valores médios do consumo de ração (CR), consumo de metionina + cistina (CMC), ganho de peso (GP), conversão alimentar (CA), viabilidade (VIAB) e uniformidade (UNIF) de codornas de corte machos, alimentadas com crescentes relações metionina + cistina: lisina digestíveis durante o período de 22 a 28 dias de idade

\begin{tabular}{lccccccr}
\hline \multirow{2}{*}{ Variáveis } & \multicolumn{9}{c}{ Relações Metionina } & \multicolumn{3}{c}{ Cistina: Lisina Digestíveis } & \multirow{2}{*}{ CV (\%)* } & \multirow{2}{*}{ Sig.** } \\
\cline { 2 - 6 } & 0,68 & 0,73 & 0,78 & 0,83 & 0,88 & & \\
\hline CR (g/ave) & 177,83 & 181,41 & 182,41 & 177,85 & 180,35 & 3,26 & 0,8217 \\
CMC (mg/ave) & 100,36 & 109,19 & 122,42 & 128,40 & 137,10 & 3,09 & 0,6801 \\
GP (g/ave) & 53,72 & 56,46 & 58,99 & 54,66 & 59,23 & 8,01 & 0,0768 \\
CA (g/g) & 3,14 & 3,22 & 3,09 & 3,26 & 3,04 & 5,21 & 0,3768 \\
VIAB (\%) & 100 & 100 & 100 & 100 & 100 & 0,00 & 0,2468 \\
UNIF (\%) & 77,97 & 72,91 & 78,57 & 73,21 & 76,78 & 18,03 & 0,8924 \\
\hline
\end{tabular}

*CV= Coeficiente de variação; ** Sig. = Significância. 
Rev. Bras. Saúde Prod. Anim., Salvador, v.17, n.2, p.162-173 abr./jun., 2016 http://www.rbspa.ufba.br

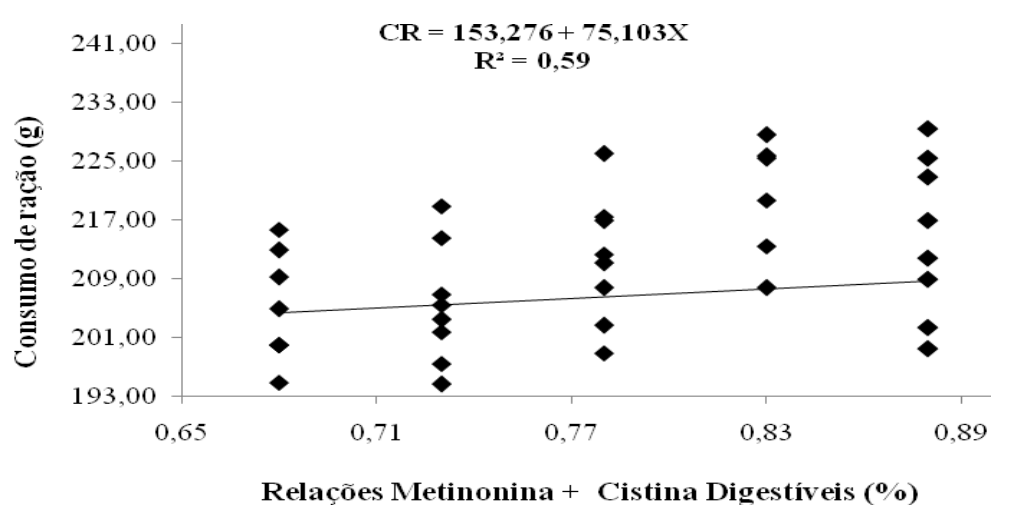

Figura 1. Consumo de ração de codornas de corte machos no período de 28 a 35 dias de idade, em função das relações metionina + cistina : lisina digestíveis nas rações

Tabela 3. Valores médios do consumo de ração $(\mathrm{CR})$, consumo de metionina + cistina (CMC), ganho de peso (GP), conversão alimentar (CA), viabilidade (VIAB) e uniformidade (UNIF) de codornas de corte machos, alimentadas com crescentes relações metionina + cistina: lisina digestíveis durante o período de 29 a 35 dias de idade

\begin{tabular}{lccccccc}
\hline \multirow{2}{*}{ Variáveis } & \multicolumn{9}{c}{ Relações Metionina + Cistina: Lisina Digestíveis } & \multirow{2}{*}{ CV $(\%) *$} & \multirow{2}{*}{ Sig.** } \\
\cline { 2 - 6 } & 0,68 & 0,73 & 0,78 & 0,83 & 0,88 & & \\
\hline CR (g/ave) & 204,67 & 205,35 & 211,60 & 224,10 & 213,42 & 4,87 & 0,0026 \\
CMC (mg/ave) & 128,94 & 137,59 & 152,36 & 170,32 & 173,83 & 4,97 & 0,0077 \\
GP (g/ave) & 42,41 & 47,15 & 49,00 & 50,58 & 49,46 & 12,83 & 0,0160 \\
CA (g/g) & 4,87 & 4,40 & 4,35 & 4,53 & 4,38 & 11,16 & 0,1581 \\
VIAB (\%) & 100 & 100 & 100 & 100 & 100 & 0,00 & 0,2751 \\
UNIF (\%) & 76,48 & 83,92 & 75,00 & 82,14 & 92,85 & 18,22 & 0,0721 \\
\hline
\end{tabular}

*CV= Coeficiente de variação; ** Sig. = Significância.

$\mathrm{O}$ consumo de metionina + cistina digestível $\left(\mathrm{CMC}=-37,53+243,589 \mathrm{X} ; \mathrm{R}^{2}\right.$ $=0,98)$ aumentou linearmente $(\mathrm{P}<0,01)$ com as crescentes relações metionina + cistina : lisina digestíveis nas rações, sendo devido ao aumento do consumo de ração e às crescentes suplementações de metionina para atingir as relações estudadas (Figura 2). Similarmente, D'Avila Lima et al. (2015) avaliando as relações ideais de metionina + cistina : lisina digestíveis em rações para codornas japonesas em fase de crescimento e início da postura, observaram aumento linear com as relações estudadas para consumo de ração, consumo de metionina + cistina: lisina, peso corporal e deposição de proteína e gordura na carcaça.

Houve aumento linear $(\mathrm{P}<0,05)$ no ganho de peso em função do aumento das relações metionina + cistina : lisina digestíveis na ração de acordo com a equação linear $\mathrm{GP}=20,585+34,757 \mathrm{X}$; $\mathrm{R}^{2}=0,74$. A equação do LRP $(\mathrm{GP}=$ 49,645 - 94,779 (0,756 - X); $\left.\mathrm{R}^{2}=0,60\right)$ também ajustou-se aos resultados, sendo a relação de 0,75 de metionina + cistina : lisina digestíveis, aquela que determina o início de um platô (Figura 3). Apesar de ter sido estimada uma relação com o modelo LRP para o ganho de peso, pelo modelo linear obtém-se melhor ajuste dos resultados, definido pelo coeficiente de determinação (maior $\mathrm{R}^{2}$ ). 
Rev. Bras. Saúde Prod. Anim., Salvador, v.17, n.2, p.162-173 abr./jun., 2016 http://www.rbspa.ufba.br

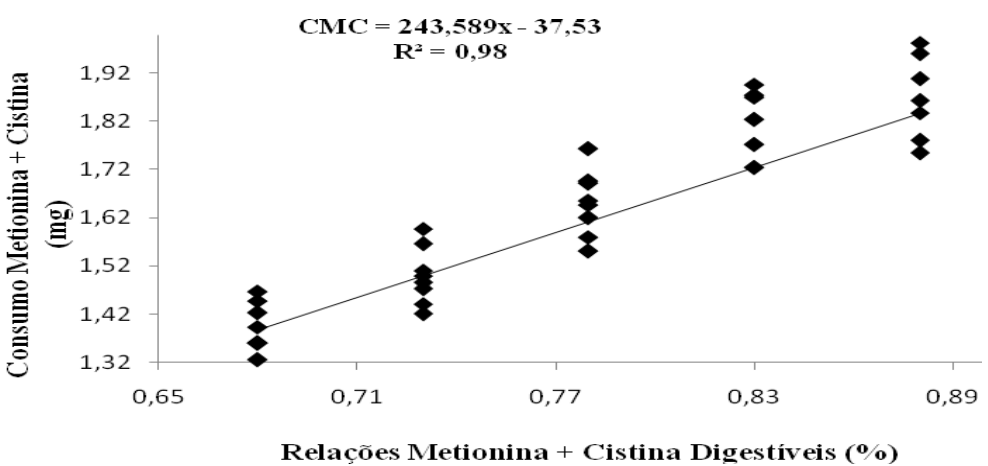

Figura 2. Consumo de metionina + cistina de codornas de corte machos no período de 28 a 35 dias de idade, em função das relações metionina + cistina: lisina digestíveis nas rações

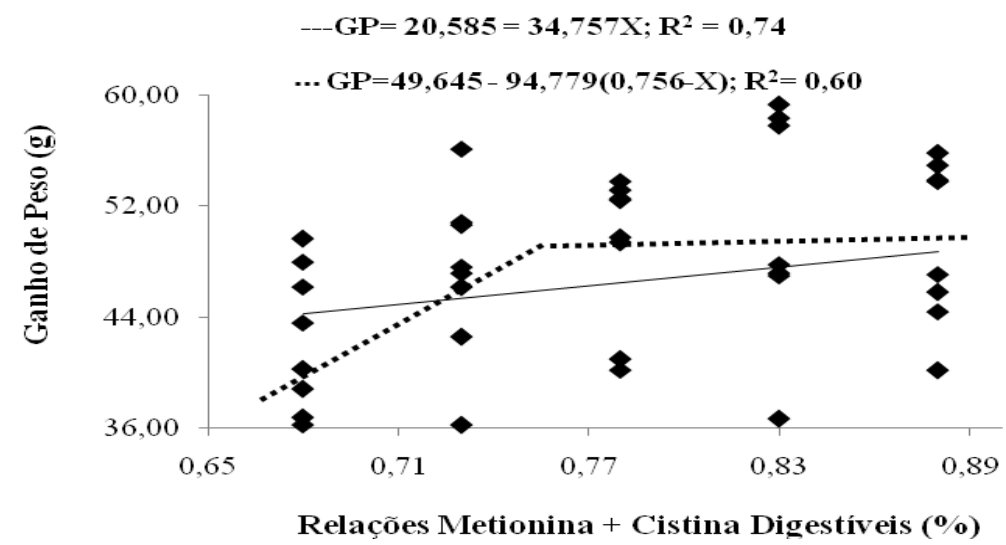

Figura 3. Equações linear e LRP do ganho de peso de codornas de corte machos no período de 28 a 35 dias de idade, em função das relações metionina + cistina: lisina digestíveis nas rações

O consumo médio diário de metionina + cistina de 18,42 para $24,82 \mathrm{mg} / \mathrm{ave} /$ dia proporcionou incremento no ganho de peso de 6,05 para 7,06g/ave/dia, conforme as relações de 0,68 para 0,88 , o que corresponde ao incremento de aproximadamente $16,6 \%$ no ganho de peso durante o período. Os resultados de D’Avila Lima et al. (2015) corroboram com o presente estudo em que os autores observaram efeito linear no ganho de peso de codornas japonesas em fase de crescimento ( 1 a 40 dias) alimentadas com as relações metionina
+ cistina : lisina digestíveis de 0,54 a 0,78 (com intervalo de 0,06 ).

A conversão alimentar das codornas não foi influenciada $(\mathrm{P} \geq 0,05)$ frente às crescentes relações metionina + cistina : lisina digestíveis nas rações.

As variáveis viabilidade e uniformidade das codornas de corte também não foram influenciadas $(\mathrm{P} \geq 0,05)$ de acordo com o aumento das relações metionina + cistina : lisina digestíveis nas rações.

Não houve efeito $(\mathrm{P} \geq 0,05)$ para o peso corporal, peso da carcaça, rendimento de carcaça e rendimento de peito das codornas alimentadas com as crescentes 
Rev. Bras. Saúde Prod. Anim., Salvador, v.17, n.2, p.162-173 abr./jun., 2016 http://www.rbspa.ufba.br

relações metionina + cistina: lisina digestíveis nas rações (Tabela 4). Entretanto, D'Avila Lima et al. (2015) observaram maior peso corporal e peso de carcaça com codornas japonesas aos 40 dias de idade, alimentadas com maiores relações metionina + cistina : lisina digestíveis (de 0,54 para 0,78 ).

No entanto, o rendimento de coxa + sobrecoxa diminuiu $(\mathrm{P}<0,01)$ de forma linear de acordo com o aumento das relações metionina + cistina: lisina digestíveis nas rações, segundo a equação: $\mathrm{RCS}=28,481-6,875 \mathrm{X} ; \mathrm{R}^{2}=$ 0,84 (Figura 4). Esse resultado pode ser justificado pelo estresse por calor em que as aves foram expostas, interferindo negativamente na produtividade das aves.

Tabela 4. Valores médios do peso corporal (PCP), peso carcaça (PC), rendimento de carcaça $(\mathrm{RC})$, rendimento de peito (RP), rendimento de coxa e sobrecoxa (RCS) e peso de penas (Pen) de codornas de corte machos alimentadas com relações crescentes de metionina + cistina: lisina digestíveis aos 35 dias de idade

\begin{tabular}{lccccccc}
\hline \multirow{2}{*}{ Variáveis } & \multicolumn{9}{c}{ Relações Metionina + cistina:Lisina digestíveis } & \multirow{2}{*}{ CV $(\%) *$} & \multirow{2}{*}{ Sig.** } \\
\cline { 2 - 6 } & 0,68 & 0,73 & 0,78 & 0,83 & 0,88 & & \\
\hline PCP (g/ave) & 245,90 & 245,27 & 258,13 & 248,25 & 246,43 & 5,43 & 0,3996 \\
PC (g/ave) & 186,13 & 187,16 & 198,26 & 191,10 & 189,15 & 5,55 & 0,4152 \\
RC (\%) & 75,64 & 76,36 & 76,91 & 77,00 & 76,79 & 2,75 & 0,2193 \\
RP(\%) & 38,59 & 38,20 & 39,47 & 39,31 & 38,65 & 4,58 & 0,5402 \\
RCS(\%) & 23,76 & 23,90 & 22,73 & 22,38 & 22,80 & 4,54 & 0,0057 \\
Pen (g/ave) & 10,78 & 10,65 & 10,80 & 11,12 & 11,05 & 11,22 & 0,4576 \\
\hline
\end{tabular}

*CV= Coeficiente de variação; ** Sig. = Significância.

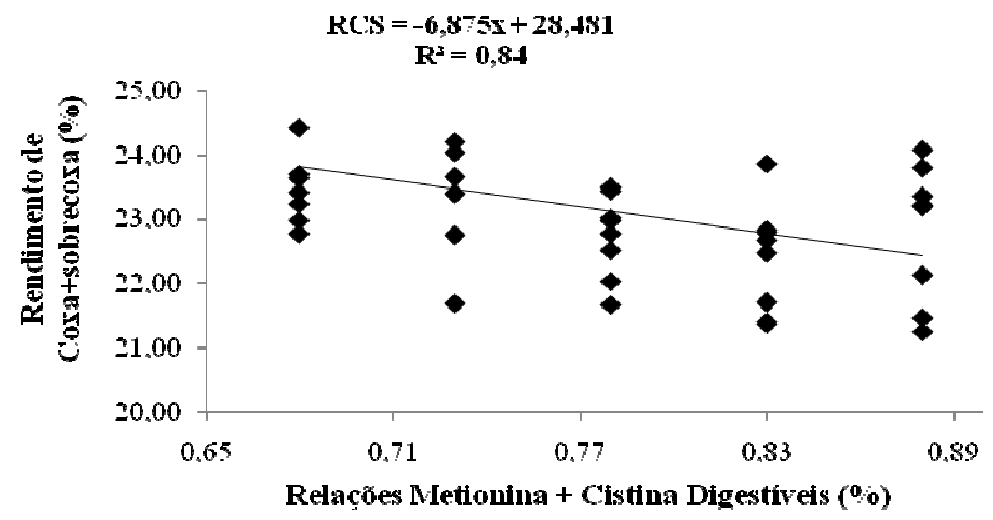

Figura 4. Rendimento de coxa+sobrecoxa de codornas de corte machos no período de 28 a 35 dias de idade, em função das relações metionina + cistina: lisina digestíveis nas rações

Os autores Habeeb et al. (1992), citados em trabalho de Oliveira Neto et al. (2000), relataram que em situações de calor, a fisiologia do animal fica alterada e assim ocorre redução do consumo de ração e a liberação de hormônios termogênicos, com consequente redução do metabolismo 
Rev. Bras. Saúde Prod. Anim., Salvador, v.17, n.2, p.162-173 abr./jun., 2016 http://www.rbspa.ufba.br

basal, dessa forma produzirá menos calor corporal. Oliveira Neto et al. (2000) afirmaram que essas alterações fisiológicas conduzem à menor produtividade dos animais, podendo, portanto, justificar menor rendimento de coxa e sobrecoxa. Além disso, para dissipar o calor corporal existe um custo energético que pode influenciar negativamente nas características de carcaça. De forma similar, Oliveira et al. (2006) observaram piores resultados de desempenho e rendimento de cortes de frangos criados em estresse térmico pelo calor e umidade elevada. Os autores relataram que os dados dos cortes nobres evidenciaram que a alta temperatura influenciou, de forma diferenciada, os músculos do corpo das aves, priorizando os da perna (coxa e sobrecoxa) em detrimento aos do peito. Por outro lado, Corrêa et al. (2010), não encontraram efeito para as características de rendimento de carcaça e cortes nobres em codornas de corte aos 35 dias de idade alimentadas com diferentes níveis de metionina + cistina. Em pesquisa com frangos de corte, Tavernari et al. (2014) ao avaliarem relações metionina + cistina: lisina digestíveis para frangos de corte, observaram aumento no peso de carcaça, de peito e filé de peito para frangos machos abatidos aos 35 dias. Mas, nestas pesquisas os índices de conforto térmico (temperatura do ar e umidade relativa do ar) das aves foram atendidos.

$\mathrm{O}$ peso de penas das codornas não foi influenciado $(\mathrm{P} \geq 0,05)$ pelas crescentes relações metionina + cistina : lisina digestíveis nas rações, indicando que o nível mais baixo utilizado para esta fase não interferiu de forma negativa na quantidade de penas das aves. Os resultados de D'Avila Lima et al. (2015) corroboram aos do presente estudo, em que codornas japonesas na fase de crescimento (1 a 40 dias) não apresentaram diferenças quanto ao empenamento ao receberem diferentes relações metionina + cistina: lisina digestíveis nas rações. Os autores justificaram que as codornas priorizaram a mantença ao invés do crescimento, utilizando principalmente a energia e proteína da ração para mantença. Leeson \& Summers (2008) relataram que o crescimento das penas das aves é constante, e para as fases pré-iniciais e de crescimento, o desenvolvimento das penas é sensível à disponibilidade de aminoácidos sulfurosos na corrente sanguínea, assim a exigência desses aminoácidos para o empenamento é mais elevada durante o crescimento das aves.

Os teores de matéria seca das carcaças das aves não foram influenciados $(\mathrm{P} \geq 0,05)$ em função das crescentes relações metionina + cistina: lisina digestíveis nas rações (Tabela 5).

Tabela 5. Valores médios dos teores de matéria seca (MS), proteína bruta (PB) e extrato etéreo (EE) da carcaça de codornas de corte machos alimentadas com relações crescentes de metionina + cistina:lisina digestíveis aos 35 dias de idade

\begin{tabular}{lccccccc}
\hline \multirow{2}{*}{ Variáveis } & \multicolumn{9}{c}{ Relações Metionina + cistina:Lisina digestíveis } & \multirow{2}{*}{ CV (\%)* } & \multirow{2}{*}{ Sig.** } \\
\cline { 2 - 5 } & 0,68 & 0,73 & 0,78 & 0,83 & 0,88 & & \\
\hline MS (\%) & 31,45 & 31,36 & 32,86 & 32,15 & 34,7 & 3,91 & 0,0922 \\
PB (\%) & 58,02 & 59,33 & 57,2 & 57,80 & 53,42 & 6,16 & 0,0089 \\
EE (\%) & 32,10 & 32,18 & 32,25 & 32,51 & 33,15 & 9,47 & 0,0390 \\
\hline
\end{tabular}

*CV= Coeficiente de variação; ** Sig. = Significância. 
No entanto, as crescentes relações metionina + cistina : lisina digestíveis da ração influenciaram $(\mathrm{P}<0,05)$ de forma linear crescente a porcentagem de extrato etéreo da carcaça $(\mathrm{EE}=20,954+$ $\left.14,899 \mathrm{X} ; \mathrm{R}^{2}=0,70\right)$ e de forma linear decrescente $(\mathrm{P}<0,01)$ a proteína bruta da carcaça $\left(\mathrm{PB}=74,184-21,883 \mathrm{X} ; \mathrm{R}^{2}=\right.$ $0,58)$. Assim, à medida que se aumentou a metionina + cistina / lisina digestíveis nas rações, maior porcentagem de gordura e menor porcentagem de proteína bruta foi depositada na carcaça. Isso indica que as maiores relações estudadas desencadearam um desequilíbrio nutricional no organismo das aves, levando-as a desaminar os aminoácidos em excesso, não sendo aproveitados para a síntese de proteína corporal, mas sim para $\mathrm{o}$ metabolismo energético $\mathrm{e}$ consequentemente favoreceu a deposição de gordura corpórea e menor síntese protéica na carcaça. Segundo Kalinowski et al. (2003) os aminoácidos em excesso ingeridos e absorvidos, quando não são utilizados para formação da proteína, são utilizados para o metabolismo energético, contribuindo assim para a deposição de gordura corporal. D'Avila Lima et al. (2015) também observaram maior deposição de gordura na carcaça de codornas japonesas em crescimento alimentadas com crescentes relações metionina + cistina: lisina nas rações.

Observou-se efeito significativo $(\mathrm{P}<0,01)$ do aumento das relações metionina + cistina : lisina digestíveis na ração sobre o balanço de nitrogênio $(\mathrm{BN}=0,155-$ $0,521 \mathrm{X} ; \mathrm{R}^{2}=0,98$ ) (Tabela 6). Para todas as relações estudadas, verificou-se resultado negativo, ou seja, a excreção nitrogenada foi se tornando mais intensa de acordo com o aumento das relações estudadas.

Tabela 6. Valores médios do balanço de nitrogênio $(\mathrm{BN})$ de codornas de corte machos alimentadas com relações crescentes de metionina + cistina: lisina digestíveis

\begin{tabular}{lccccccc}
\hline \multirow{2}{*}{ Variável } & \multicolumn{9}{c}{ Relações Metionina + Cistina $:$ Lisina Digestíveis } & \multirow{2}{*}{ CV (\%)* } & \multirow{2}{*}{ Sig.** } \\
\cline { 2 - 5 } & 0,68 & 0,73 & 0,78 & 0,83 & 0,88 & & \\
\hline BN & $-0,205$ & $-0,218$ & $-0,248$ & $-0,281$ & $-0,305$ & 32,50 & 0,0074 \\
\hline *CV= Coeficiente de variação; ${ }^{* *}$ Sig. = Significância.
\end{tabular}

Segundo Scottá et al. (2012), o balanço de nitrogênio tende a ser positivo para frangos em crescimento, devido a estes estarem retendo nitrogênio para a deposição de proteína corporal. Deste modo, os resultados negativos observados no presente estudo são justificados pela idade avançada das codornas. Assim, justifica-se que com o aumento das relações metionina + cistina: lisina nas rações, os aminoácidos sulfurosos foram catabolizados pelo organismo das aves e a fração nitrogenada excretada, o que diminuiu a eficiência na retenção de nitrogênio pela ave, favorecendo a maior deposição de gordura corporal e ao mesmo tempo menor síntese protéica para tecido magro.

Recomenda-se para o período de 22 a 28 dias de idade das codornas de corte machos, a relação metionina + cistina: lisina digestíveis de 0,68 e para o período de 29 a 35 dias de idade, a relação metionina + cistina: lisina digestíveis de 0,88 . 
Rev. Bras. Saúde Prod. Anim., Salvador, v.17, n.2, p.162-173 abr./jun., 2016 http://www.rbspa.ufba.br ISSN 15199940

\section{AGRADECIMENTOS}

À Fundação de Amparo à Pesquisa do Estado de Minas Gerais (FAPEMIG) e à Ajinomoto do Brasil Indústria e Comércio de Alimentos Ltda., pelo aporte financeiro e pela doação dos aminoácidos, respectivamente.

\section{REFERÊNCIAS}

CORREAA, G.S.S.; SILVA M.A.; CORREAA A.B. FONTES, D.O.; SANTOS, G.G.; FREITAS, L.S.; WENCESLAU, R.R. Níveis de metionina + cistina para características de desempenho e de carcaça em codornas de corte EV2. Arquivo Brasileiro de Medicina Veterinária e Zootecnia, v.62, n.4, p.940-947, 2010.

COSTA, F.G.P.; RODRIGUES, V.P.; GOULART, C.C.; LIMA NETO, R.C.; SOUZA, J. G.; SILVA, J.H.V. Exigências de lisina digestível para codornas japonesas na fase de postura. Revista

Brasileira de Zootecnia, v.37, n.12, p.2136-2140, 2008.

D'AVILA LIMA, , H.J; BARRETO, S.L.T.; DONZELE, J.L.;TINOCO, I.F.F.;RIBAS, N.S. Ideal ratio of digestible methionine plus cystine to digestible lysine for growing Japanese quails. Revista Colombiana de Ciencias Pecuaria, v.28, p.313-322, 2015.

EMMERT, J.L.; BAKER, D.H. Use of the ideal protein concept for precision formulation of amino acid levels in broiler diets. Journal Applied Poultry, v.6, p.462 - 470, 1997.

LEESON, S.; SUMMERS, D.J. Feeding programs for broiler chickens. In: LEESON, S.; SUMMERS, D.J. Commercial poultry nutrition. 5.ed. Guelph: Nottingham University Press, 2008. 413p.
KALINOWSKI, A.; MORAN JUNIOR, E.T; WYATT, C.L. Methionine and cystine requirements of slow- and fastfeathering broiler males from three to six weeks of age. Poultry Science, v.82, p.1428-1437. 2003.

OLIVEIRA NETO, A.R.; OLIVEIRA, R.F.M.; DONZELE, J.L.; ROSTAGNO, H.S.; FERREIRA, R.A.;

MAXIMIANO, H.C.; GASPARINO, E. Efeito da Temperatura Ambiente sobre o Desempenho e Características de Carcaça de Frangos de Corte Alimentados com Dieta Controlada e Dois Níveis de Energia Metabolizável. Revista Brasileira de Zootecnia, v.29, n.1, p.183-190, 2000.

OLIVEIRA, R.F.M.; DONZELE, J.L.; ABREU, M.L.T.; Ferreira, R.A.; VAZ, R.G.M.V.; CELLA, P.S. Efeitos da temperatura e da umidade relativa sobre o desempenho e o rendimento de cortes nobres de frangos de corte de 1 a 49 dias de idade. Revista Brasileira de Zootecnia, v.35, n.3, p.797-803, 2006.

ROSTAGNO, H.S.; ALBINO, L.F.T.; DONZELE, J. L.; GOMES, P.C., OLIVEIRA, R.F.M.; LOPES, D.C.; FERREIRA, A.S.; BARRETO, S.L.T.; EUCLIDES, R.F. Tabelas brasileiras para aves e suínos: composição de alimentos e exigências nutricionais. 3.ed. Viçosa, MG: UFV, 2011. 252p.

SARAIVA, E.P.; OLIVEIRA, R.G.M.; DONZELE, J.L.; SILVA, F.C.O.; VAZ, R.G.M.V.; SIQUEIRA, J.C.; MANNO, M.C.; OLIVEIRA, W.P. Níveis de treonina digestível em rações para leitoas dos 15 aos $30 \mathrm{~kg}$ mantidas em ambiente de alta temperatura. Revista Brasileira de Zootecnia, v.35, n.2, p.485-490, 2006. 
Rev. Bras. Saúde Prod. Anim., Salvador, v.17, n.2, p.162-173 abr./jun., 2016 http://www.rbspa.ufba.br ISSN 15199940

SCOTTÁ, B.A.; PEREIRA, C.M.C.;

BERNARDINO, V.M.P. Energia

Metabolizável e Aminoácidos

Digestíveis dos Alimentos para Frangos

de Corte. Revista Nutritime, v.9, n.4, p.1861-1874, 2012.

SILVA, D.J.; QUEIRÓZ, A.C.D.

Análises de alimentos: métodos químicos e biológicos. 3.ed. Viçosa, MG: UFV, 2004. 235p.

SILVA, E.L.; SILVA, J.H.V.; JORDÃO FILHO, J.; RIBEIRO, M.L.G. Efeito do plano de nutrição sobre o rendimento de carcaça de codornas tipo carne. Ciência e Agrotecnologia, v.31, n.2, p.514-522, 2012.

SILVA, J.H.V.; COSTA, F.G.P. Tabelas para codornas japonesas e européias. 3.ed. Jaboticabal, SP: Funep, 2009. 107p.

SOUZA, M.S. Determinação das faixas de conforto térmico para codornas de corte de diferentes idades. 2013. 87p. Tese (Doutorado em Zootecnia) - Universidade Federal de Viçosa.

TAVERNARI, F.C.; BERNAL, L.E.P.; ROSTAGNO, H.S.; ALBINO, L.F.T.; VIEIRA, R.A. Relação metionina + cistina / lisina digestível para frangos de corte cobb. Revista Ceres, v.61, n.2, p.193-201, 2014.

TON, A.P.S.; FURLAN, A.C.; MARTINS, E.N.; BATISTA, E.; PASQUETTI, T.J.; SCHERER, C.; IWAHASHI, A.S.; QUADROS, T.C.O. Nutritional requirements of digestible threonine for growing meat-type quails. Revista Brasileira de Zootecnia, v.42, n.7, p.504-510, 2013.

Data de recebimento: $12 / 12 / 2014$

Data de aprovação: 04/04/2016 